\title{
Analysis of school damage due to Lombok earthquake on August 2018
}

\author{
M Sofian Asmirza ${ }^{1}$ \\ ${ }^{1}$ Civil Engineering, Engineering Faculty of North Sumatra University, Medan, Indonesia
}

\begin{abstract}
The Lombok earthquakes on 5 and 19 August, 2018 have caused fatality and damage buildings including houses and schools. It was reported that the Lombok earthquake had caused damage to at least 606 schools in West Nusa Tenggara. Following the earthquake, the field survey was carried out in a few days to collecting data of damaged schools in Lombok. The global positions of surveyed schools were recorded during the survey to identify the geological and seismicity condition surrounding area. The data were analyzed to understand the cause of the damaged. The damage pattern of the schools is also analyzed and then compared to the other related studies. The damage on the schools in Lombok Island generally has a result of insufficient quality of the building materials. Further, understanding the earthquake resistant building for earthquake prone areas is the most basic knowledge to be informed to the Local Government who has authority to manage the schools. This study suggests for establish Local formal rule of related to minimal requirement for earthquake resistant school building following the microzonation.
\end{abstract}

\section{Introduction}

The last earthquakes 2018 in Lombok have taken more that 500 lives. These earthquakes were twin, the first earthquake was on land and occurred on July 29 with the magnitude of 7.0 on 5 of August and M 6,9 on 19 of August 2018 [1]. It was categorized as twin since those earthquakes have different magnitude less than 0.2 and happened within 3 years.

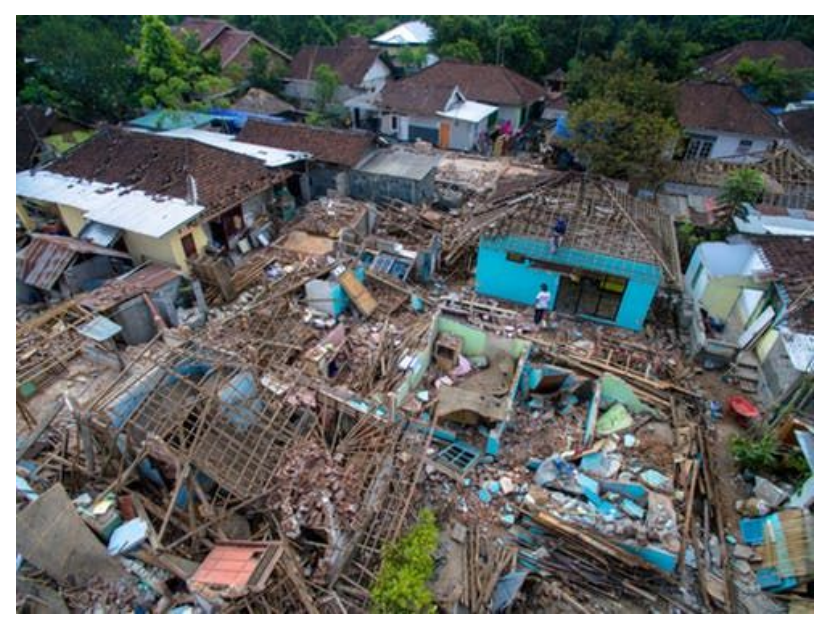

Fig. 1. The Damage in Lombok earthquake 2018 [2].

The damage caused by the earthquakes was in the form of collapsed building and houses, cracked soil, and liquefaction. The main recent damage and collapse of buildings due to earthquakes occurred generally due to the weakness of the buildings for anticipating the ground motion.

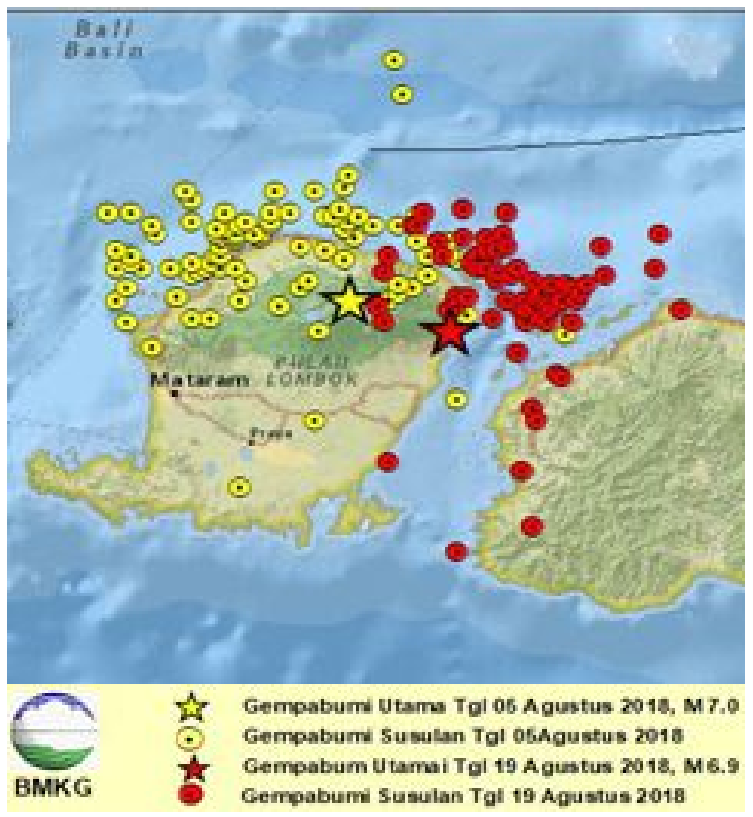

Fig. 2. The map of the epicenter of the Lombok earthquake on 5 and 19 August 2018 [3].

It was reported that the Lombok earthquake had caused damage to at least 606 schools in West Nusa Tenggara [4]. This study was conducted for investigating the causes of the damage on school building due to the Lombok Earthquake.

\footnotetext{
* Corresponding author: sofyan0076@yahoo.co.uk
} 


\section{Methodology}

First, the library survey was conducted to understand the damage of building, mainly due to the earthquake. The strength of the general building which need to fight against the vertical and horizontal must be clear. It was also collected some damage pattern of past and recent building due to earthquakes. Since the schools in Indonesia generally have only single floor, then the earthquake resistant houses are met to be understood.

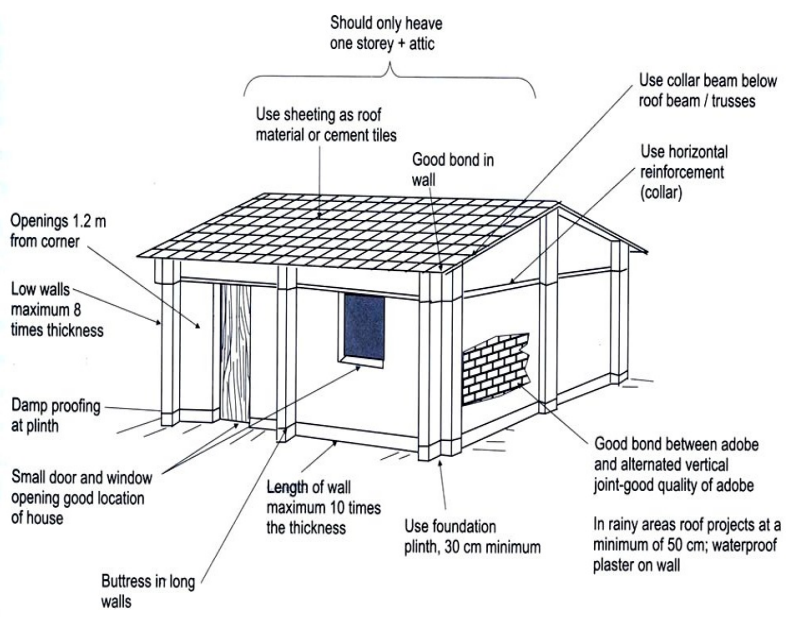

Fig. 3. The general understanding of earthquake resistant building [5].

Soon, the field survey was carried out in a few days following the earthquake. The survey was conducted in order to collecting data of damaged schools in Lombok. During the survey, the global positions of the observed schools were recorded. This position may be needed to identify the geological and seismicity condition surrounding area.

The collected data were the analyzed to understand the cause of the damaged. The damage pattern of the schools is also analyzed and then compared to the other related studies. This analyses then was reported in this paper.

\section{Results and Discussions}

\subsection{SD Negeri 02 Obel-obel}

The main structure of observed building of SD Negeri 02 Obel-obel (Fig. 4) is made of brick masonry wall. This building is used for reading class. The main structure of the building may also be categorized as confined wall (Fig. 5).

This building is still firmly standing but it suffered from detail damage. It can be categorized as light to medium damage. First, the connection between the wall and the confining reinforce (RC) concrete was cracked (Fig. 6). It seems there is not enough steel bar to connect the walls and the main RC columns. Second, the overlaps main steel bar is to short. It is at least 40 time of the main bar diameter. Since then, the joints of perimeter beam and column was pulled out during the earthquake.

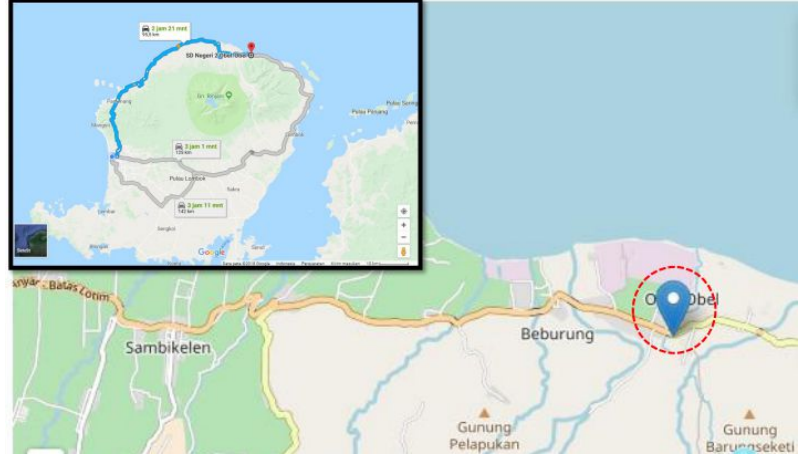

Fig. 4. Location of SD 02 Obel-obel.

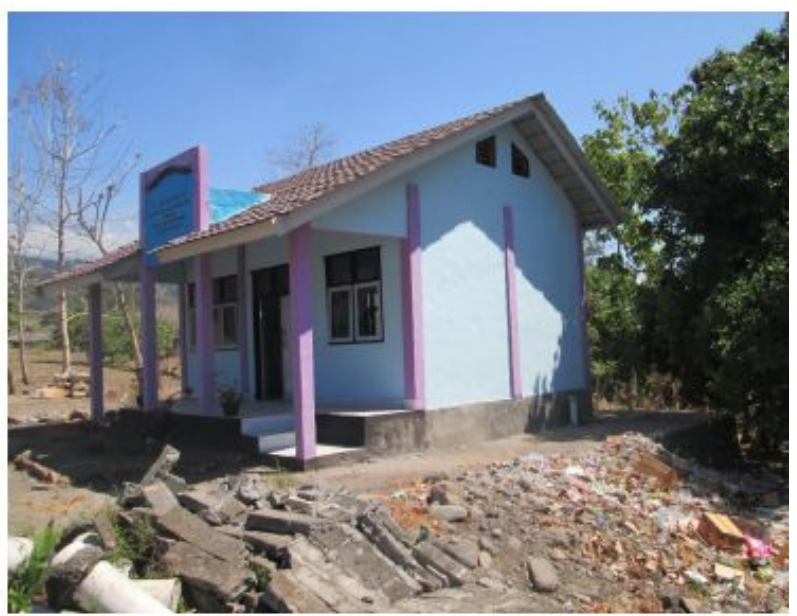

Fig. 5. The general strucuture of SD 02 Obel-obel
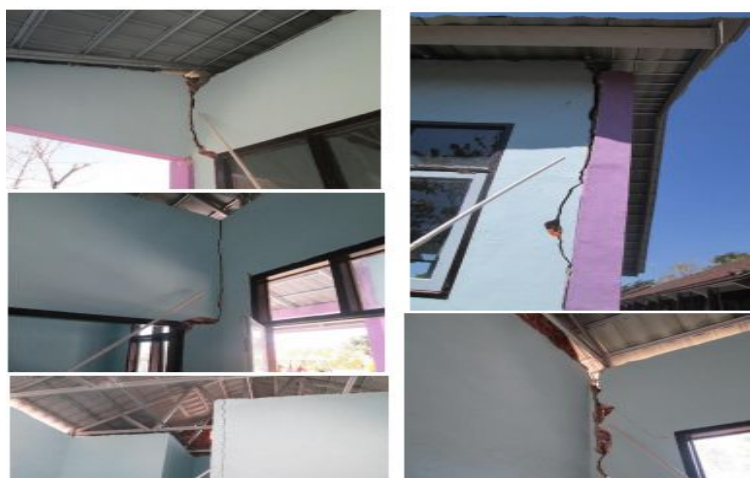

(a) Reading Room

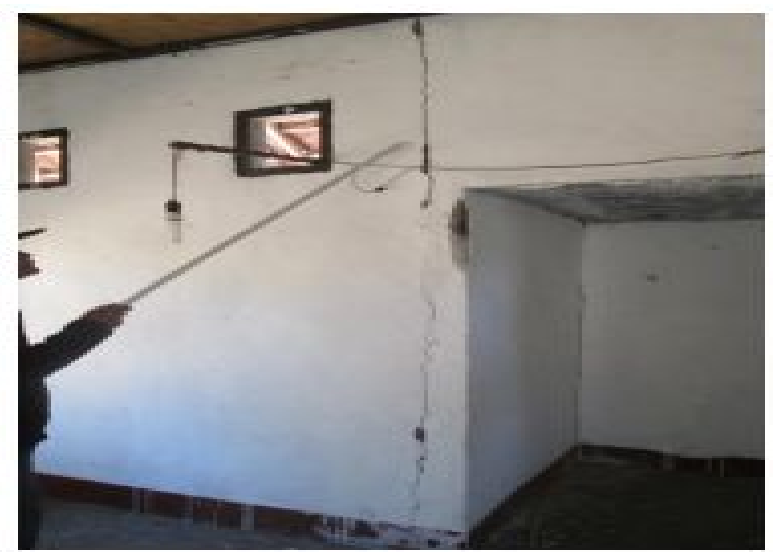

(b) Praying Room 


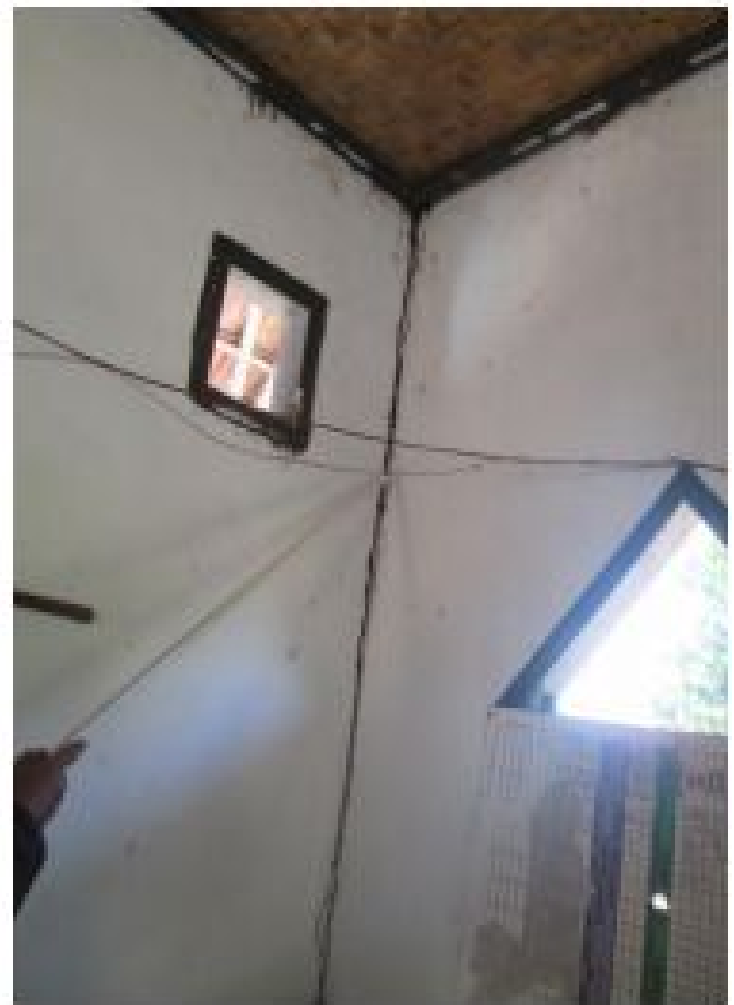

Fig. 6. The Damage type of SD 02 Obel-obel

\subsection{Paud Terpadu Pemenang Bersatu (PB)}

The main structure of observed building of Paud Terpadu Pemenang Bersatu (Fig. 7) is made of brick masonry wall. This building is used for reading class. The main structure of the building may also be categorized as confined wall (Fig. 5).

This building is still firmly standing but it suffered from detail damage. It can be categorized as light to medium damage. First, the connection between the wall and the confining reinforce (RC) concrete was cracked (Fig. 6). It seems there is not enough steel bar to connect the walls and the main RC columns. Second, the overlaps main steel bar is to short. It is at least 40 time of the main bar diameter. Since then, the joints of perimeter beam and column was pulled out during the earthquake.

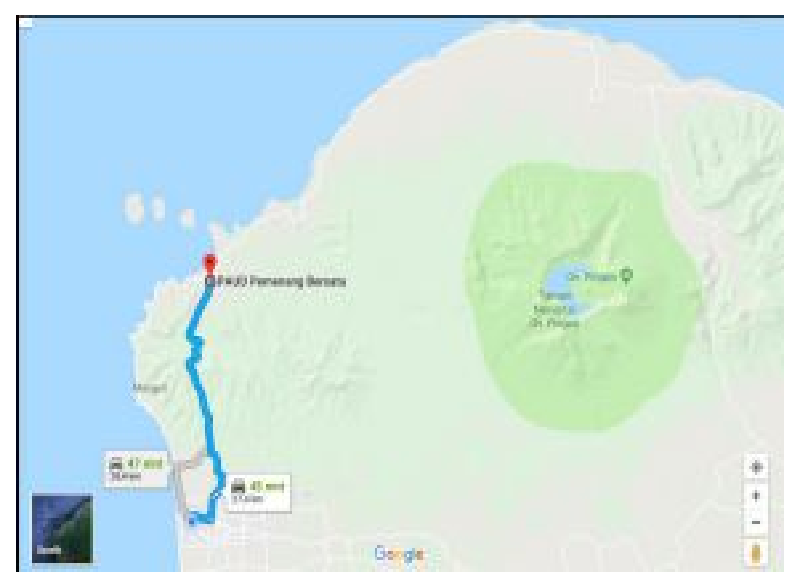

Fig. 7. Location of Paud Terpadu PB.

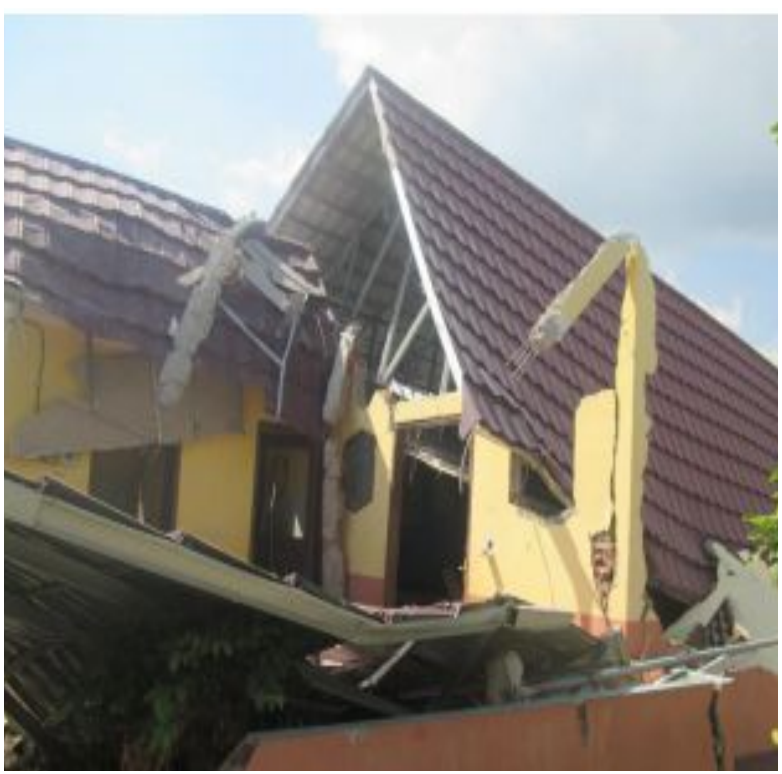

Fig. 8. The total damage strucuture of Paud Terpadu PB

Second building, there are many cracks on the wall connected to the confining reinforce (RC) concrete (Fig. 9). It indicates there is not good enough connection between the walls and the main RC concrete. Since the crack also existed in horizontal direction where generally no need connected bar, in shows the material of the building is not in good quality. Moreover, the roofs of the buildings are made of burned clay which may have a relatively weight compared to the metal roofs.

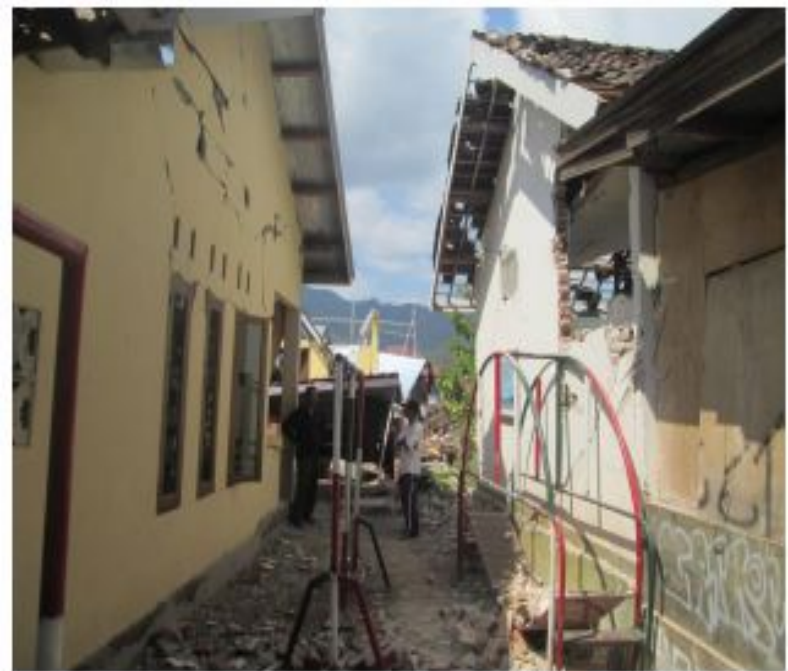

Fig. 9. The Heavy Damage type of Paud Terpadu PB

\subsection{SMP Negeri 01 Pemenang}

The structure of observed building of SMP Negeri 1 Pemenang (Fig. 10) is made of confined brick masonry wall. The building is used for learning classes. The building collapse badly in one side (Fig. 11). The rst of the building can be said still firmly standing even it suffered from small detail damage. This building relatively new building which can be seen from the 
material used. It uses the light formed steel for roof construction and uses light metal roof material as well. The side damage indicates the low quality of material and it connection. The wall - roof connection just only 'simple touch' each other. Structurally it considered to be No Connection at all.

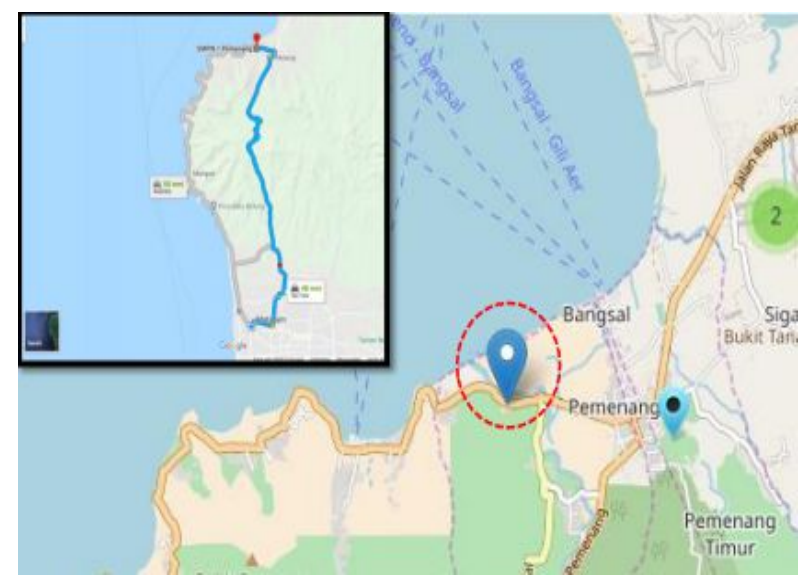

Fig. 10. Location of SMP N 01 Pemenang.

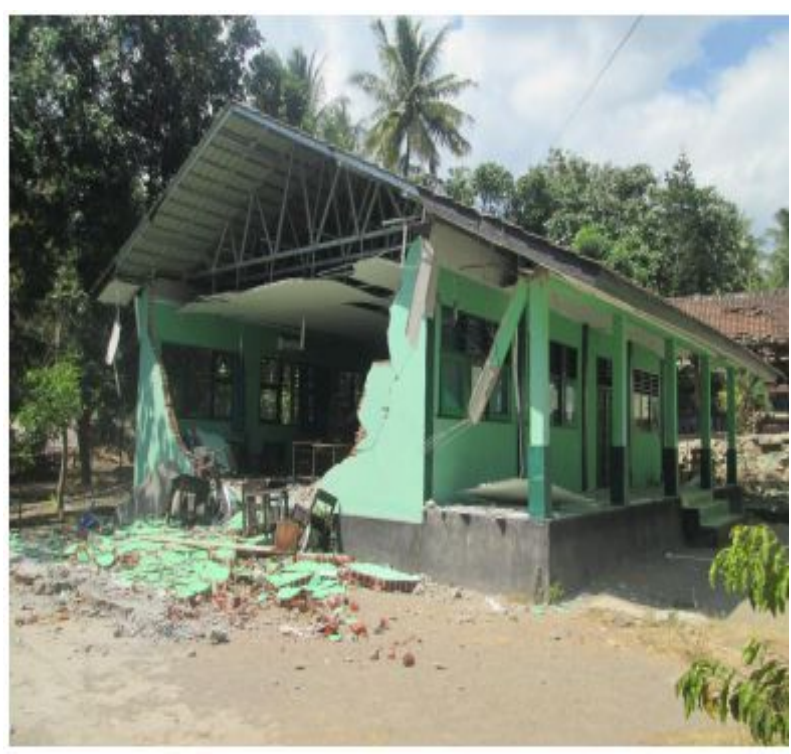

Fig. 11. The damage of of SMP N 01 Pemenang.

\section{Conclusions}

Mased on the survey data and damage analysis of the school building in Lombok Island, it can be crawn general conclusion of damage building reasons, that are the insufficient quality of the building materials, weak joint, heavy material in used, and not quite good construction.

For further earthquake safety building, it was suggested for implementing understanding the earthquake resistant building for earthquake prone areas is the most basic knowledge to be informed to the Local Government who has authority to manage the schools. Based on this study it also suggested for establishing Local formal rule of related to minimal requirement for earthquake resistant school building following the microzonation.

\section{References}

1. Daryono, BMKG: Gempa Kuat Lombok Tergolong Gempa Kembar, https://tekno.tempo.co/read/ $1118727 /$ bmkg -gempa- kuat -lombok- tergolonggempa-kembar). Accessed on 23/9/(2019).

2. Raditya, Rumah-rumah hancur setelah gempa bumi di Lombok pada Agustus, (2018) http://theconversation.com/mengapa-polagoncangan-gempa-lombok-2018-bisa-fluktuatif-dantidak-lazim-108603, Accessed on 20/9/2019.

3. Dwikorita Karnawati, Pulau Lombok Kembali Diguncang Gempabumi M=7.0, Tidak Berpotensi Tsunami, https://www.bmkg.go.id/pressrelease $/ ? \mathrm{p}=$ pulau-lombok-kembali-diguncanggempabumi-m7-0-tidak-berpotensitsunami\&tag=press-release \&lang=ID

4. Eko Cs, Laporan Kegiatan Pendataan / Analisis Kerusakan Gedung Sekolah Di Lombok Barat Dan Lombok Utara, PPPTK Bidang Bangunan dan Listrik Medan, (2018)

5. Dominik Lang and Friends, The World Housing Encyclopedia (WHE), http://db.worldhousing.net/static/data/100147/102490_134_14.jpg, Accessed on 23/9/(2019). 